\title{
HIV integrase and the swan song of the CD4 T cells?
}

Jérôme Estaquier ${ }^{1,2^{*}}$, John Zaunders ${ }^{3}$ and Mireille Laforge ${ }^{1}$

\begin{abstract}
T cell apoptosis represents one pathophysiological mechanism associated with AIDS. Herein, we discuss the recent report published by A. Cooper et al. in Nature (June 2013) regarding HIV viral DNA integration-mediated apoptosis.
\end{abstract}

Keywords: HIV, Apoptosis, DNA, p53, DNA-PK

\section{Background}

Over twenty years ago it was hypothesized that CD4+ T lymphocyte depletion during HIV infection resulted from apoptosis $[1,2]$, and since then numerous research teams have strived to identify the associated cellular and molecular mechanisms. As early as 1991, studies by Drs. D. Richman [3] and A. Hovanessian [4] showed that the virus induces apoptosis in lymphoblastoid $\mathrm{T}$ cell lines or mitogen-activated primary $\mathrm{CD} 4+\mathrm{T}$ cells in vitro. This programmed cell death is independent of caspase activation [5-10], the main effector proteases involved in apoptosis [11].

\section{Main text}

A paper recently published by A. Cooper $e t$ al. in Nature [12] suggests that integration of viral DNA is responsible for this apoptosis via activation of p53 by DNA-dependent protein kinase (DNA-PK), a protein kinase participating in DNA damage response. The authors show that apoptosis is only displayed by cells that do not express p24 antigen. An analysis of in vitro stimulated cells obtained from three HIV-infected individuals not receiving therapy suggested that the cells not expressing p24 antigen died in a proportion of 70 to $>90 \%$, but only $10-25 \%$ of these cells contained HIV DNA by qPCR. Furthermore, p24+ cells - representing 0.1-0.5\% of CD4 T cells - died at a rate of $30-70 \%$. This result implies that overall more than $90 \%$ of the CD4 T lymphocytes from HIV infected individuals underwent apoptosis in vitro, a proportion

\footnotetext{
* Correspondence: estaquier@yahoo.fr

${ }^{1}$ CNRS FRE 3235, Université Paris Descartes, Paris, France

${ }^{2}$ Université Laval, Centre de Recherche en Infectiologie, Québec, Canada

Full list of author information is available at the end of the article
}

that seems to be incompatible with the in vivo status of these HIV-infected patients having CD4 cell counts up to 600 per $\mathrm{mm}^{3}$. The study also shows that blocking viral integration with raltegravir, an inhibitor of HIV integrase, decreased the occurrence of cell death not only in T/B lymphoblastoid cell line CEMX174, but also in primary CD4 T cells activated with PHA/IL-2. Likewise, a virus bearing a mutated integrase (D64V) caused less apoptosis. The authors propose that viral integration was responsible for cell death. Thus, lymphocytes would die before the virus gets a chance to replicate. Considering this, one has to wonder what advantage a pathogenic agent may gain from such a mechanism. Previous work by Dr. F. Bushman [13] had shown that it may be the accumulation of viral DNA and not its integration that could induce this apoptosis during activation of CD4+ T lymphocytes. This accumulation of viral DNA has also been proposed to induce the death of $\mathrm{T}$ cells in a human tonsil model [14] - described as early as the 1990s by Margolis' group as supporting viral replication [15]. This process is accompanied by chronic inflammatory response that can be associated with caspase- 1 activation, a caspase involved in pyroptotic cell death [16].

Cooper et al. furthermore propose that a phosphorylation of proteins $\mathrm{p} 53$ and $\mathrm{H} 2 \mathrm{AX}$ accompanies this process via DNA-PK activation. Pharmacological inhibition of DNA-PK activation not only prevents phosphorylation of these two molecules, but cell death as well. The role of the DNA-PK pathway is largely studied in the context of double-strand break repair through non-homologous end joining (NHEJ). In 1999, Daniel and colleagues [17] reported that DNA-PK activity increases as a consequence of retroviral integration. The authors also showed that an 
HIV-1-based virus vector induced death in scid pre-B cell lines This death was proposed to be due to a defect in DNA-PK in these cell lines, resulting in a lack of DNA repair needed to complete the retroviral integration. Several groups subsequently showed that DNA damage sensors ATM, ATR, DNA-PK, and PARP-1 were, however, not required for efficient HIV-1 integration [18,19], and a protective role of DNA-PK was only observed against death induced by high levels of retrovirus integration. Thus, DNA-PK may exert a protective effect on the infected cells, a claim exactly opposite to that of Cooper and colleagues. Moreover, it has been reported that the activity of HIV-1 integrase stimulates an ATMdependent DNA damage response, and that a deficiency of this kinase sensitizes cells to retrovirus-induced cell death [20]. Paradoxically, the inhibitor used in that study was KU55933, which was the same molecule utilized by Cooper and colleagues to show that ATM inhibition does not relieve cell death upon HIV infection. A possible explanation of such controversial results should be the difference of cells used in these studies, cell lines versus primary T cells.

Lastly, the authors show that inhibiting p53 activation with a pharmacological agent, pifithrin, also blocks CD4 T cell apoptosis. However, the nature of the cells expressing p53 and DNA-PK was not assessed by the authors, although implicitly they suggested p24- cells. On the contrary, several groups, including ours, have previously shown that phosphorylation of p53 and expression of target genes only occurred in cells replicating the virus (p24+) [21-23]. We have also recently shown that silencing p53 with interfering RNA reduces apoptosis [23] and increases viral replication in primary CD4 T cells. Therefore, we favour the hypothesis that p53 activation constitutes a stress-sensing mechanism, allowing auto-elimination of infected cells, and thus a host altruistic defence mechanism limiting viral dissemination. This programmed cell death is associated with lysosomal destabilization $[10,23]$, which requires viral replication, since bystander cells - exposed to the virus, but not infected - do not display lysosomal destabilization.

Although increased activation of CD4 T cells during HIV-1 infection promotes viral production, the fact remains that the proportion of productively infected CD4 T cells in lymphoid tissue is very low, $0.25-1 \%$ or less of the cells that contain HIV DNA, which in turn represent about $10-20 \%$ of all CD4 T cells (reviewed in [24]). Much of this HIV DNA, at least in circulating memory CD4 T cells during untreated HIV infection, is in a labile unintegrated linear form or in episomal 2-LTR circles, [25]. After extended antiretroviral treatment of HIV-infected subjects, the cells containing integrated HIV DNA are long-lived $[25,26]$. The analysis of related simian immunodeficiency viruses (SIV), comparing those that are pathogenic for their hosts, such SIVmac239 or SIVmac251, to the non-pathogenic SIVagm, SIVsm or SIVmnd, has shown that, despite a sustained viral replication in both pathogenic and non-pathogenic infections, only pathogenic models display an exacerbated apoptosis of CD4 T lymphocytes [27-30], beginning during primary infection [31-33]. Studies have shown that non-infected cells die mostly by apoptosis [34,35]. The level of apoptosis is a predictor of the rate of progression to AIDS and correlates with the innate immune response $[36,37]$. Furthermore, other work has shown in patients said to be discordant with respect to their immunovirological status - i.e. individuals for whom antiviral therapy is efficient, but in whom CD4 depletion continues that there is an abnormal level of CD4+ T lymphocyte apoptosis [38]. Taken all together, it seems unlikely that integration of HIV DNA per se is responsible for the apoptosis observed in lymphoid tissues in vivo and clinically relevant CD4 depletion.

Considering the various non-human primate (NHP) models, it is noteworthy that the immune response of CD4 T lymphocytes of AGM monkeys or sooty mangabeys is extremely limited $[29,39,40]$ and that their weakly activated central memory cells contain most of the viral DNA [41]. Several studies have indeed shown that chronic activation of the immune system may induce an activation-induced cell death (AICD)-type apoptosis via death receptors, particularly Fas and its ligand [32,42-48], with the latter being more weakly expressed in non-pathogenic infection models [49]. Furthermore, a role has been proposed for Trail and its death receptors, TRAIL-R1/R2, via type-1 interferons [50], although this work remains controversial $[46,49,51,52]$. Moreover, Trail has little influence on $\mathrm{T}$ lymphocyte homeostasis, as opposed to Fas, or the major part played by Bim, a pro-apoptotic member of the Bcl-2 family [53-55]. A role for Bim has been described, first in NHPs infected by SIV [46], but also in HIV patients [56]. Therefore, increased apoptosis could be due to activation, rather than infection of cells by HIV-1. However, addition of cyclosporine A, an inhibitor of $\mathrm{T}$ cell activation, to antiretroviral therapy (ART) does not provide apparent virologic or immunologic benefit [57].

Furthermore, the absence of co-signals by APCs [58] and the production of immunosuppressive cytokines, such as interleukin-10 or TGF- $\beta$, may trigger T cell apoptosis $[43,59,60]$ involving Bim. It is noteworthy that adding exogenous factors, such as interleukins-2, -12 or -15 , can prevent apoptosis of CD4 T lymphocytes ex vivo [44,61,62], via induction of anti-apoptotic cellular factors such as Bcl2 or Bcl- $\mathrm{x}$, antagonists of Bim. However, immunotherapy based on IL-2 did not yield any benefit during the chronic phase of either HIV or SIV-infections [63,64].

IL-7 is the most important anti-apoptotic exogenous signal for T cell survival in vivo. We have shown directly 
that highly activated CD8 T cells in subjects during primary HIV-1 infection have reduced IL-7 receptor and reduced Bcl-2 and rapidly undergo apoptosis spontaneously in vitro, unless cultured with the common gamma-chain cytokines IL-2 or IL-15 [65]. However, IL-7 signalling may additionally enhance integration of HIV-1 into the genome of target CD4 $\mathrm{T}$ cells [66] as well as re-activation of productive infection from latently infected cells [67]. Furthermore, its impact on CD4 $\mathrm{T}$ death seems to depend on the duration of exposure to this cytokine or on production of accessory cytokines. It indeed displays no discernible effect on purified CD4 T lymphocytes [44], whereas added to PBMCs it prevents apoptosis after 4 days of culture [68].

Increased IL-7 levels in progressive HIV-1 infection may also increase the expression of the coreceptor CXCR4, resulting in a greater risk of emergence of an X4-using viral strain [69], and in turn IL-7 may prove to be more deleterious and pro-apoptogenic with these X4 viral strains, as it causes an increase of Fas [70-72]. Not only does the interaction between the viral envelope and the CD4 molecule prime the cells to undergo apoptosis [73-77], but interaction with viral coreceptors CCR5 and CXCR4 may also induce apoptosis and enhance Fas-mediated cell death independently of immune activation [32,78-80]. Given this possible role of co-receptors in initiating apoptosis, does Maraviroc, a CCR5 inhibitor, have an enhanced role in vivo in inhibiting CD4 T cell death?

Considering NHP models, a simple question must be asked -WHY do these viruses, albeit "cytolytic" after in vitro stimulation, not cause in their hosts a very rapid depletion of CD4 $\mathrm{T}$ lymphocytes, in all models of infection? In fact, based on the suggestion by Cooper et al. that every cell integrating HIV DNA automatically dies, non-pathogenic SIV infection in NHP should not be possible. Moreover, what would be the possible advantage for the virus to activate and deplete the immune system if this leads to a very rapid death of its host? It should be remembered that HIV-1 infection is a recent zoonosis, to which HIV-1 has presumably not yet completely adapted. Clearly the activation of the immune system that results from HIV-1 infection may increase target cells for productive infection in the short term, but may also relatively rapidly lead to the demise of the host and presumably reduce overall the chance of transmission (notwithstanding the size of the HIV-1 pandemic). Conversely, does a non-pathogenic SIV in its natural host intentionally limit lymphocyte activation more than the strong activation of a pathogenic strain of SIV or HIV? Is the virus trying to minimize the CD4 response, to render it relatively anergic, in order to facilitate its own dissemination? Likewise, does the localization of the virus into sites where the immune response is tightly controlled, such as the intestine, represent an evasion strategy, a way to hide in sanctuaries characterized by weak activation? This could account for viral persistence in HIV-infected patients in spite of several years of highly-active therapy. Therefore, like Orpheus do non-pathogenic viruses render the cells resistant to the song of death.

\section{Conclusions}

In conclusion, this new study from Cooper et al. proposes an apoptosis molecular mechanism linked to viral integration associated with the activation of p53 and DNA-PK. However, this concept is difficult to reconcile with known in vivo events, and, furthermore, an eventual therapeutic strategy aimed at blocking p53 or DNA-PK could be highly risky, by promoting either viral replication or cancer. Due to the complexity of the biochemical apoptotic pathways described leading to CD4 cell death, inhibiting this process in vivo presents a real challenge.

\section{Competing interests}

The authors declare that they have no competing interests.

\section{Authors' contributions}

EJ, JZ, and LM wrote the manuscript. All authors read and approved the final manuscript.

\section{Acknowledgement}

This work was funded by grants to JE from the Agence Nationale de Recherches sur le Sida et les Hépatites Virales (ANRS). JE thanks the Canada Research Chair program for financial assistance.

\section{Author details}

${ }^{1}$ CNRS FRE 3235, Université Paris Descartes, Paris, France. ${ }^{2}$ Université Laval, Centre de Recherche en Infectiologie, Québec, Canada. ${ }^{3}$ St Vincent's Centre for Applied Medical Research, St Vincent's Hospital, Darlinghurst, NSW, Australia.

Received: 12 August 2013 Accepted: 6 November 2013

Published: 9 December 2013

\section{References}

1. Ameisen JC, Estaquier J, Idziorek T: From AIDS to parasite infection: pathogen-mediated subversion of programmed cell death as a mechanism for immune dysregulation. Immunol Rev 1994, 142:9-51.

2. Ameisen JC, Capron A: Cell dysfunction and depletion in AIDS: the programmed cell death hypothesis. Immunol Today 1991, 12:102-105.

3. Terai C, Kornbluth RS, Pauza CD, Richman DD, Carson DA: Apoptosis as a mechanism of cell death in cultured T lymphoblasts acutely infected with HIV-1. J Clin Invest 1991, 87:1710-1715.

4. Laurent-Crawford AG, Krust B, Muller S, Riviere Y, Rey-Cuille MA, Bechet JM, Montagnier L, Hovanessian AG: The cytopathic effect of HIV is associated with apoptosis. Virology 1991, 185:829-839.

5. Gandhi RT, Chen BK, Straus SE, Dale JK, Lenardo MJ, Baltimore D: HIV-1 directly kills CD4+ T cells by a Fas-independent mechanism. J Exp Med 1998, 187:1113-1122.

6. Petit F, Arnoult D, Lelievre JD, Moutouh-de Parseval L, Hance AJ, Schneider P, Corbeil J, Ameisen JC, Estaquier J: Productive HIV-1 infection of primary CD4 + T cells induces mitochondrial membrane permeabilization leading to a caspase-independent cell death. J Biol Chem 2002, 277:1477-1487.

7. Lenardo MJ, Angleman SB, Bounkeua V, Dimas J, Duvall MG, Graubard MB, Hornung F, Selkirk MC, Speirs CK, Trageser C, Orenstein JO, Bolton DL: Cytopathic killing of peripheral blood CD4(+) T lymphocytes by human immunodeficiency virus type 1 appears necrotic rather than apoptotic and does not require env. J Virol 2002, 76:5082-5093.

8. Moutouh L, Estaquier J, Richman DD, Corbeil J: Molecular and cellular analysis of human immunodeficiency virus-induced apoptosis in 
lymphoblastoid T-cell-line-expressing wild-type and mutated CD4 receptors. J Virol 1998, 72:8061-8072

9. Lelievre JD, Petit F, Perrin L, Mammano F, Arnoult D, Ameisen JC, Corbeil J, Gervaix A, Estaquier J: The density of coreceptors at the surface of CD4+ T cells contributes to the extent of human immunodeficiency virus type 1 viral replication-mediated T cell death. AIDS Res Hum Retroviruses 2004, 20:1230-1243.

10. Laforge M, Petit F, Estaquier J, Senik A: Commitment to apoptosis in CD4 (+) T lymphocytes productively infected with human immunodeficiency virus type 1 is initiated by lysosomal membrane permeabilization, itself induced by the isolated expression of the viral protein Nef. J Virol 2007, 81:11426-11440.

11. Thornberry NA, Lazebnik Y: Caspases: enemies within. Science 1998 281:1312-1316.

12. Cooper A, Garcia M, Petrovas C, Yamamoto T, Koup RA, Nabel GJ: HIV-1 causes CD4 cell death through DNA-dependent protein kinase during viral integration. Nature 2013, 498:376-379.

13. Li L, Olvera JM, Yoder KE, Mitchell RS, Butler SL, Lieber M, Martin SL, Bushman FD: Role of the non-homologous DNA end joining pathway in the early steps of retroviral infection. Embo J 2001, 20:3272-3281.

14. Doitsh G, Cavrois M, Lassen KG, Zepeda O, Yang Z, Santiago ML, Hebbeler AM, Greene WC: Abortive HIV infection mediates CD4 T cell depletion and inflammation in human lymphoid tissue. Cell 2010, 143:789-801.

15. Grivel JC, Margolis LB: CCR5- and CXCR4-tropic HIV-1 are equally cytopathic for their T-cell targets in human lymphoid tissue. Nat Med 1999, 5:344-346.

16. Petit F, Corbeil J, Lelievre JD, Moutouh-de Parseval L, Pinon G, Green DR Ameisen JC, Estaquier J: Role of CD95-activated caspase-1 processing of IL-1 beta in TCR-mediated proliferation of HIV-infected CD4(+) T cells. Eur J Immunol 2001, 31:3513-3524.

17. Daniel R, Katz RA, Skalka AM: A role for DNA-PK in retroviral DNA integration. Science 1999, 284:644-647.

18. Ariumi $Y$, Turelli $P$, Masutani M, Trono D: DNA damage sensors ATM, ATR, DNA-PKcs, and PARP-1 are dispensable for human immunodeficiency virus type 1 integration. J Virol 2005, 79:2973-2978.

19. Baekelandt V, Claeys A, Cherepanov P, De Clerca E, De Strooper B, Nuttin B, Debyser Z: DNA-Dependent protein kinase is not required for efficient lentivirus integration. J Virol 2000, 74:11278-11285.

20. Lau A, Swinbank KM, Ahmed PS, Taylor DL, Jackson SP, Smith GC, O'Connor MJ: Suppression of HIV-1 infection by a small molecule inhibitor of the ATM kinase. Nat Cell Biol 2005, 7:493-500.

21. Genini D, Sheeter D, Rought S, Zaunders JJ, Susin SA, Kroemer G, Richman DD, Carson DA, Corbeil J, Leoni LM: HIV induces lymphocyte apoptosis by a p53-initiated, mitochondrial- mediated mechanism. Faseb J 2001, 15:5-6.

22. Imbeault $M$, Giguere $K$, Ouellet $M$, Tremblay MJ: Exon level transcriptomic profiling of HIV-1-infected CD4(+) T cells reveals virus-induced genes and host environment favorable for viral replication. PLoS Pathog 2010, 8:e1002861

23. Laforge M, Limou S, Harper F, Casartelli N, Rodrigues V, Silvestre R, Haloui $H$, Zagury JF, Senik A, Estaquier J: DRAM triggers lysosomal membrane permeabilization and cell death in CD4(+) T cells infected with HIV. PLOS Pathog 2013, 9:e1003328.

24. Haase AT: Population biology of HIV-1 infection: viral and CD4+ T cell demographics and dynamics in lymphatic tissues. Annu Rev Immunol 1999, 17:625-656.

25. Koelsch KK, Liu L, Haubrich R, May S, Havlir D, Gunthard HF, Ignacio CC, Campos-Soto P, Little SJ, Shafer R, Robbins GK, D'Aquila RT, Kawano Y, Young K, Dao P, Spina CA, Richman DD, Wong JK: Dynamics of total, linear nonintegrated, and integrated HIV-1 DNA in vivo and in vitro. $J$ Infect Dis 2008, 197:411-419.

26. Siliciano JD, Kajdas J, Finzi D, Quinn TC, Chadwick K, Margolick JB, Kovacs C, Gange SJ, Siliciano RF: Long-term follow-up studies confirm the stability of the latent reservoir for HIV-1 in resting CD4+ T cells. Nat Med 2003, 9:727-728.

27. Hurtrel B, Petit F, Arnoult D, Muller-Trutwin M, Silvestri G, Estaquier J: Apoptosis in SIV infection. Cell Death Differ 2005, 12(Suppl 1):979-990

28. Estaquier J, Idziorek T, de Bels F, Barre-Sinoussi F, Hurtrel B, Aubertin AM, Venet $A$, Mehtali M, Muchmore E, Michel $P$, et al: Programmed cell death and AIDS: significance of T-cell apoptosis in pathogenic and nonpathogenic primate lentiviral infections. Proc Natl Acad Sci USA 1994, 91:9431-9435
29. Silvestri G, Sodora DL, Koup RA, Paiardini M, O'Neil SP, McClure HM, Staprans SI, Feinberg MB: Nonpathogenic SIV infection of sooty mangabeys is characterized by limited bystander immunopathology despite chronic high-level viremia. Immunity 2003, 18:441-452.

30. Gougeon ML, Lecoeur H, Boudet F, Ledru E, Marzabal S, Boullier S, Roue R, Nagata S, Heeney J: Lack of chronic immune activation in HIV-infected chimpanzees correlates with the resistance of T cells to Fas/Apo-1 (CD95)-induced apoptosis and preservation of a T helper 1 phenotype. J Immunol 1997, 158:2964-2976.

31. Monceaux V, Estaquier J, Fevrier M, Cumont MC, Riviere Y, Aubertin AM, Ameisen JC, Hurtrel B: Extensive apoptosis in lymphoid organs during primary SIV infection predicts rapid progression towards AIDS. Aids 2003, 17:1585-1596.

32. Viollet L, Monceaux V, Petit F, Ho Tsong Fang R, Cumont MC, Hurtrel B, Estaquier J: Death of CD4+ T cells from lymph nodes during primary SIVmac251 infection predicts the rate of AIDS progression. J Immunol 2006, 177:6685-6694.

33. Cumont MC, Diop O, Vaslin B, Elbim C, Viollet L, Monceaux V, Lay S, Silvestri G, Le Grand R, Muller-Trutwin M, Hurtrel B, Estaquier J: Early divergence in lymphoid tissue apoptosis between pathogenic and nonpathogenic simian immunodeficiency virus infections of nonhuman primates. J Virol 2008, 82:1175-1184

34. Finkel TH, Tudor-Williams G, Banda NK, Cotton MF, Curiel T, Monks C, Baba TW, Ruprecht RM, Kupfer A: Apoptosis occurs predominantly in bystander cells and not in productively infected cells of HIV- and SIV-infected lymph nodes [see comments]. Nat Med 1995, 1:129-134.

35. Li Q, Duan L, Estes JD, Ma ZM, Rourke T, Wang Y, Reilly C, Carlis J, Miller CJ, Haase AT: Peak SIV replication in resting memory CD4+ T cells depletes gut lamina propria CD4+ T cells. Nature 2005, 434:1148-1152.

36. Campillo-Gimenez L, Laforge M, Fay M, Brussel A, Cumont MC, Monceaux V, Diop O, Levy Y, Hurtrel B, Zaunders J, Corbeil J, Elbim C, Estaquier J: Nonpathogenesis of simian immunodeficiency virus infection is associated with reduced inflammation and recruitment of plasmacytoid dendritic cells to lymph nodes, not to lack of an interferon type I response, during the acute phase. J Virol 2010, 84:1838-1846.

37. Campillo-Gimenez L, Cumont MC, Fay M, Kared H, Monceaux V, Diop O, Muller-Trutwin M, Hurtrel B, Levy Y, Zaunders J, Dy M, Leite-de-Moraes MC, Elbim C, Estaquier J: AIDS progression is associated with the emergence of IL-17-producing cells early after simian immunodeficiency virus infection. J Immunol 2010, 184:984-992.

38. Benveniste O, Flahault A, Rollot F, Elbim C, Estaquier J, Pedron B, Duval X, Dereuddre-Bosquet N, Clayette P, Sterkers G, Simon A, Ameisen JC, Leport C: Mechanisms involved in the low-level regeneration of CD4+ cells in HIV-1-infected patients receiving highly active antiretroviral therapy who have prolonged undetectable plasma viral loads. J Infect Dis 2005, 191:1670-1679.

39. Villinger F, Folks TM, Lauro S, Powell JD, Sundstrom JB, Mayne A, Ansari AA: Immunological and virological studies of natural SIV infection of diseaseresistant nonhuman primates. Immunol Lett 1996, 51:59-68.

40. Chakrabarti LA, Luckay A, Marx PA: A divergent simian immunodeficiency virus from sooty mangabey with an atypical Tat-TAR structure. AIDS Res Hum Retroviruses 2001, 17:1155-1165.

41. Paiardini M, Cervasi B, Reyes-Aviles E, Micci L, Ortiz AM, Chahroudi A, Vinton C, Gordon SN, Bosinger SE, Francella N, Hallberg PL, Cramer E, Schlub T, Chan ML, Riddick NE, Collman RG, Apetrei C, Pandrea I, Else J, Munch J, Kirchhoff F, Davenport MP, Brenchley JM, Silvestri G: Low levels of SIV infection in sooty mangabey central memory $\mathrm{CD}(4)(+) \mathrm{T}$ cells are associated with limited CCR5 expression. Nat Med 2011, 17:830-836.

42. Katsikis PD, Wunderlich ES, Smith CA, Herzenberg LA: Fas antigen stimulation induces marked apoptosis of T lymphocytes in human immunodeficiency virus-infected individuals. J Exp Med 1995, 181:2029-2036.

43. Estaquier J, Idziorek T, Zou W, Emilie D, Farber CM, Bourez JM, Ameisen JC: T helper type $1 / T$ helper type 2 cytokines and T cell death: preventive effect of interleukin 12 on activation-induced and CD95 (FAS/APO-1)mediated apoptosis of CD4+ T cells from human immunodeficiency virus- infected persons. J Exp Med 1995, 182:1759-1767.

44. Estaquier J, Tanaka M, Suda T, Nagata S, Golstein P, Ameisen JC: Fas-mediated apoptosis of CD4+ and CD8+ T cells from human immunodeficiency virus-infected persons: differential in vitro preventive effect of cytokines and protease antagonists. Blood 1996, 87:4959-4966. 
45. Baumler CB, Bohler T, Herr I, Benner A, Krammer PH, Debatin KM: Activation of the CD95 (APO-1/Fas) system in T cells from human immunodeficiency virus type-1-infected children. Blood 1996, 88:1741-1746.

46. Arnoult D, Petit F, Lelievie JD, Lecossier D, Hance A, Monceaux V, Ho Tsong Fang R, Huntrel B, Ameisen JC, Estaquier J: Caspase-dependent and -independent T-cell death pathways in pathogenic simian immunodeficiency virus infection: relationship to disease progression. Cell Death Differ 2003, 10:1240-1252.

47. Badley AD, Dockrell DH, Algeciras A, Ziesmer S, Landay A, Lederman MM, Connick E, Kessler H, Kuritzkes D, Lynch DH, Roche P, Yagita H, Paya CV: In vivo analysis of Fas/FasL interactions in HIV-infected patients. J Clin Invest 1998, 102:79-87.

48. Algeciras A, Dockrell DH, Lynch DH, Paya CV: CD4 regulates susceptibility to Fas ligand- and tumor necrosis factor- mediated apoptosis. J Exp Med 1998, 187:711-720.

49. Laforge M, Campillo-Gimenez L, Monceaux V, Cumont MC, Hurtrel B, Corbeil J, Zaunders J, Elbim C, Estaquier J: HIV/SIV infection primes monocytes and dendritic cells for apoptosis. PLoS Pathog 2011, 7:e1002087.

50. Herbeuval JP, Boasso A, Grivel JC, Hardy AW, Anderson SA, Dolan MJ, Chougnet C, Lifson JD, Shearer GM: TNF-related apoptosis-inducing ligand (TRAIL) in HIV-1-infected patients and its in vitro production by antigen-presenting cells. Blood 2005, 105:2458-2464.

51. Lecossier D, Bouchonnet F, Schneider P, Clavel F, Hance AJ: Discordant increases in CD4+ T cells in human immunodeficiency virus- infected patients experiencing virologic treatment failure: role of changes in thymic output and T cell death. J Infect Dis 2001, 183:1009-1016.

52. Chehimi J, Papasavvas E, Tomescu C, Gekonge B, Abdulhaqq S, Raymond A, Hancock A, Vinekar K, Carty C, Reynolds G, Pistilli M, Mounzer K, Kostman J, Montaner L: Inability of plasmacytoid dendritic cells to directly lyse HIVinfected autologous CD4+ T cells despite induction of tumor necrosis factor-related apoptosis-inducing ligand. J Virol 2010, 84:2762-2773.

53. Weant AE, Michalek RD, Khan IU, Holbrook BC, Willingham MC, Grayson JM: Apoptosis regulators Bim and Fas function concurrently to control autoimmunity and CD8+ T cell contraction. Immunity 2008, 28:218-230.

54. Hutcheson J, Scatizzi JC, Siddiqui AM, Haines GK 3rd, Wu T, Li QZ, Davis LS, Mohan C, Perlman H: Combined deficiency of proapoptotic regulators Bim and Fas results in the early onset of systemic autoimmunity. Immunity 2008, 28:206-217.

55. Hughes PD, Belz GT, Fortner KA, Budd RC, Strasser A, Bouillet P: Apoptosis regulators Fas and Bim cooperate in shutdown of chronic immune responses and prevention of autoimmunity. Immunity 2008, 28:197-205.

56. van Grevenynghe J, Procopio FA, He Z, Chomont N, Riou C, Zhang Y, Gimmig S, Boucher G, Wilkinson P, Shi Y, Yassine-Diab B, Said EA, Trautmann L, El Far M, Balderas RS, Boulassel MR, Routy JP, Haddad EK, Sekaly RP: Transcription factor FOXO3a controls the persistence of memory CD4(+) T cells during HIV infection. Nat Med 2008, 14:266-274.

57. Markowitz M, Vaida F, Hare CB, Boden D, Mohri H, Hecht FM, Kalayjian RC, Conrad A, Mildvan D, Aberg J, Hogan C, Kilby JM, Balfour HH Jr, Schafer K, Richman D, Little $S$ : The virologic and immunologic effects of cyclosporine as an adjunct to antiretroviral therapy in patients treated during acute and early HIV-1 infection. J Infect Dis 2010, 201:1298-1302.

58. Ameisen JC, Estaquier J, Idziorek T, De Bels F: The relevance of apoptosis to AIDS pathogenesis. Trends Cell Biol 1995, 5:27-32.

59. Clerici M, Sarin A, Coffman RL, Wynn TA, Blatt SP, Hendrix CW, Wolf SF Shearer GM, Henkart PA: Type 1/type 2 cytokine modulation of T-cel programmed cell death as a model for human immunodeficiency virus pathogenesis. Proc Natl Acad Sci USA 1994, 91:11811-11815.

60. Cumont MC, Monceaux V, Viollet L, Lay S, Parker R, Hurtrel B, Estaquier J: TGF-beta in intestinal lymphoid organs contributes to the death of armed effector CD8 T cells and is associated with the absence of virus containment in rhesus macaques infected with the simian immunodeficiency virus. Cell Death Differ 2007, 14:1747-1758.

61. Chehimi J, Marshall JD, Salvucci O, Frank I, Chehimi S, Kawecki S, Bacheller D, Rifat S, Chouaib S: IL-15 enhances immune functions during HIV infection. J Immunol 1997, 158:5978-5987.

62. Mueller YM, Makar V, Bojczuk PM, Witek J, Katsikis PD: IL-15 enhances the function and inhibits CD95/Fas-induced apoptosis of human CD4+ and CD8+ effector-memory T cells. Int Immunol 2003, 15:49-58.

63. Abrams D, Levy Y, Losso MH, Babiker A, Collins G, Cooper DA, Darbyshire J, Emery S, Fox L, Gordin F, Lane HC, Lundgren JD, Mitsuyasu R, Neaton JD, Phillips A, Routy JP, Tambussi G, Wentworth D: Interleukin-2 therapy in patients with HIV infection. N Engl J Med 2009, 361:1548-1559.
64. Garibal J, Laforge M, Silvestre R, Mouhamad S, Campillo-Gimenez L, Levy $Y$, Estaquier J: IL-2 immunotherapy in chronically SIV-infected Rhesus macaques. Virol J 2012, 9:220.

65. Zaunders JJ, Moutouh-de Parseval L, Kitada S, Reed JC, Rought S, Genini D, Leoni L, Kelleher A, Cooper DA, Smith DE, Grey P, Estaquier J, Little S, Richman DD, Corbeil J: Polyclonal proliferation and apoptosis of CCR5+ T lymphocytes during primary human immunodeficiency virus type 1 infection: regulation by interleukin (IL)-2, IL-15, and Bcl-2. J Infect Dis 2003, 187:1735-1747

66. Verhoeyen E, Dardalhon V, Ducrey-Rundquist O, Trono D, Taylor N, Cosset FL: IL-7 surface-engineered lentiviral vectors promote survival and efficient gene transfer in resting primary T lymphocytes. Blood 2003, 101:2167-2174.

67. Scripture-Adams DD, Brooks DG, Korin YD, Zack JA: Interleukin-7 induces expression of latent human immunodeficiency virus type 1 with minimal effects on T-cell phenotype. J Virol 2002, 76:13077-13082.

68. Vassena L, Proschan M, Fauci AS, Lusso P: Interleukin 7 reduces the levels of spontaneous apoptosis in CD4+ and CD8+ T cells from HIV-1-infected individuals. Proc Natl Acad Sci USA 2007, 104:2355-2360.

69. Brieu N, Portales P, Carles MJ, Corbeau P: Interleukin-7 induces HIV type 1 R5-to-X4 switch. Blood 2011, 117:2073-2074.

70. Lelievre JD, Petit F, Arnoult D, Ameisen JC, Estaquier J: Interleukin 7 increases human immunodeficiency virus type $1 \mathrm{LAl}$-mediated Fas-induced T-cell death. J Virol 2005, 79:3195-3199.

71. Nunnari G, Xu Y, Acheampong EA, Fang J, Daniel R, Zhang C, Zhang H, Mukhtar M, Pomerantz RJ: Exogenous IL-7 induces Fas-mediated human neuronal apoptosis: potential effects during human immunodeficiency virus type 1 infection. J Neurovirol 2005, 11:319-328.

72. Fluur C, De Milito A, Fry TJ, Vivar N, Eidsmo L, Atlas A, Federici C, Matarrese P, Logozzi M, Rajnavolgyi E, Mackall CL, Fais S, Chiodi F, Rethi B: Potential role for IL-7 in Fas-mediated T cell apoptosis during HIV infection. J Immuno/ 2007, 178:5340-5350.

73. Banda NK, Bernier J, Kurahara DK, Kurrle R, Haigwood N, Sekaly RP, Finkel TH: Crosslinking CD4 by human immunodeficiency virus gp120 primes T cells for activation-induced apoptosis. J Exp Med 1992, 176:1099-1106.

74. Oyaizu N, McCloskey TW, Coronesi M, Chirmule N, Kalyanaraman VS, Pahwa S: Accelerated apoptosis in peripheral blood mononuclear cells (PBMCs) from human immunodeficiency virus type- 1 infected patients and in CD4 cross-linked PBMCs from normal individuals. Blood 1993, 82:3392-3400.

75. Oyaizu N, McCloskey TW, Than S, Hu R, Kalyanaraman VS, Pahwa S: Cross-linking of CD4 molecules upregulates Fas antigen expression in lymphocytes by inducing interferon-gamma and tumor necrosis factor-alpha secretion. Blood 1994, 84:2622-2631.

76. Kameoka M, Kimura T, Zheng YH, Suzuki S, Fujinaga K, Luftig RB, Ikuta K: Protease-defective, gp120-containing human immunodeficiency virus type 1 particles induce apoptosis more efficiently than does wild-type virus or recombinant gp120 protein in healthy donor-derived peripheral blood T cells. J Clin Microbiol 1997, 35:41-47.

77. Esser MT, Bess JW Jr, Suryanarayana K, Chertova E, Marti D, Carrington M, Arthur LO, Lifson JD: Partial activation and induction of apoptosis in CD4 (+) and CD8(+) T lymphocytes by conformationally authentic noninfectious human immunodeficiency virus type 1. J Virol 2001, 75:1152-1164.

78. Berndt C, Mopps B, Angermuller S, Gierschik P, Krammer PH: CXCR4 and CD4 mediate a rapid CD95-independent cell death in CD4(+) T cells. Proc Natl Acad Sci USA 1998, 95:12556-12561.

79. Estaquier J, Lelievre JD, Petit F, Brunner T, Moutouh-De Parseval L, Richman DD, Ameisen JC, Corbeil J: Effects of antiretroviral drugs on human immunodeficiency virus type 1-induced CD4(+) T-cell death. J Virol 2002, 76:5966-5973.

80. Lelievre JD, Mammano F, Arnoult D, Petit F, Grodet A, Estaquier J, Ameisen JC: A novel mechanism for HIV1-mediated bystander CD4+ T-cell death: neighboring dying cells drive the capacity of HIV1 to kill noncycling primary CD4+ T cells. Cell Death Differ 2004, 11:1017-1027.

doi:10.1186/1742-4690-10-149

Cite this article as: Estaquier et al:: HIV integrase and the swan song of the CD4 T cells? Retrovirology 2013 10:149. 